\title{
Costing Logistics Services
}

\author{
A. Hatzis ${ }^{1}$, A. Koulidou ${ }^{2}$, D. Folinas ${ }^{3}$ \\ ${ }^{1,2}$ Department of Accounting, Alexander Technological Educational Institute of Thessaloniki, Greece \\ ${ }^{3}$ Department of Logistics, Alexander Technological Educational Institute, Branch of Katerini, Greece \\ 1'tasos_hatzis@yahoo.gr, ${ }^{2}$ agathi.koulidou@gmail.com, ${ }^{3}$ dfolinas@gmail.com
}

\begin{abstract}
Third Party Logistics (3PL) providers' paradigm has grown into a critical and common strategic approach, due to the benefits of the outsourcing model. Over the past two decades, 3PL's sector has played a critical role in the Greek economy. Logistics providers have extended their scope beyond traditional transportation and warehousing activities to also include many other main logistics services such as procurement, distribution, inventory management, packaging, and order processing services. In the services-oriented business sector (in general) the realization of the true costs of the provided services is a critical success factor. Specifically, a 3PL company by assessing the costs of services can confidently pursue the logistics objective of providing desired customer service at the least total cost. This paper presents and evaluates the costing systems that the 3PL's companies have used. It is based on a survey that is focused on logistics providers in Northern Greece. This survey aimed at first to identify the adopted costing system, to assess its significance for both the provision of services and the designing - redesigning of services' portfolio, to estimate the degree of satisfaction by top managers, and to recognize the problems regarding the existing costing system such as the non-value added logistics services.
\end{abstract}

Keywords: third party logistics, outsourcing, costing, survey, Greece.

\section{Introduction}

Third Party Logistics (3PL) paradigm has grown into a critical and common strategic approach, due to outsourcing trends in the new business arena. In essence, the concept of 3PL can be defined as the outsourcing of logistics activities to outside (third) companies (3PL's) (Blanchard, 2007; Christopher, 2005). The main benefits of this approach are (Ellram and Cooper, 1996):

- Lower cost: with outsourcing logistics services a company achieves a reduction of capital expenditures (equipment, storage and transportation facilities, warehouse and distribution centers). Its standard costs are converted to variable costs.

- Higher quality: 3PL's provide enhanced customer service capabilities, reduction in

*Corresponding Author average order- cycle length improved operational efficiency, combined with high experience.

Over the past two decades, 3PL's have extended their scope beyond traditional transportation and warehousing activities to also include many other core logistics services such as procurement, distribution, inventory management, packaging, and order processing / customer services (Titone, 1996). It is believed that only on realizing the true costs of the above services a firm can confidently pursue the logistics objective of providing desired customer service at the least total cost (Goldsby and Closs, 2000). This is achieved only by identifying the nonadded value logistics activities, as well as, by examining how the practice of outsourcing can increase the value of provided services (McIvor, 2000). 
Thus, in today's complex and competitive environment a 3PL company needs to rely on an effective and efficient costing system so as to make the right decisions. For example to verify whether or not their services and/or customers are profitable. Inappropriate approaches to costing might cause distorted information, result in making wrong decisions and non-acceptable business performance.

This paper presents and evaluates the costing systems that the 3PL's companies have used. It is based on a survey that referred to logistics providers in Northern Greece. This survey aimed at first to identify the adopted costing system, to estimate the degree of satisfaction by managers, and to recognize the problems regarding the existing costing system. It is organized as follows. First, the basic concepts and main characteristics of costing systems / models are presented. Then, findings of a survey regarding the costing systems that the 3PL's companies in Northern Greece use are evaluated. Finally, a discussion of the implications of findings and thoughts is stated.

\section{Costing systems}

At first, three questions need to be answered regarding the application of costing systems in the examined sector:

1. What is a cost model?

2. Why is significant in 3PL's?, and

3 . Which are the main costing systems?

According to Kaplan (1984), a cost model (or cost system), is a tool that companies use so as to have a right understanding about the cost to "run" their businesses. This can be done through analysis of the main functions that any cost model should perform: 1) Evaluation of inventory and measurement of the cost of goods and services sold for financial purposes, 2) Estimation of the cost of activities, products, services, and customers; and 3) Provision of economic feedback to managers about process efficiency.

One of the purposes of a cost model is to gather and analyze data generated in the company in order to gain useful information for making decisions. Therefore, the usefulness of a cost model may be evaluated depending on its capacity to generate the right information to make the right managerial decisions. According to Pohlen and La Londe (1994), companies need more detailed financial and nonfinancial information to identify opportunities for taking costs out of the supply channel and for re-engineering their logistics processes. They argued that the success of these efforts will largely depend on the ability of the firm's cost accounting system to trace costs related to specific products, customers, supply channels, or logistics activities. Furthermore, logistics cost will become more important in product pricing decisions as firms seek to reduce costs and attain a competitive advantage (La Londe and Pohlen, 1996.

After synthesizing the relative literature (Kaplan, 1984; Cooper and Kaplan, 1996; 1987), the main costing systems can be categorized based on the:

- Production process costs. There are two costing methods:

- Process costing, and

- Job-order costing.

- Product costs. In this situation we can distinguish:

- Direct (or variable or marginal) costing, and

- Absorption (or full) costing.

Most common categorization is the second approach. According to Garrison, Noreen and Brewer (2004) in Variable Costing only manufactured costs are treated as product costs (it can be directly traced to producing specific goods or services). There are three (3) types of direct cost: 1) Direct Material (Cost of material that can be specifically identified with the product, such as packaging materials), 2) Direct Labor (Cost of personnel in warehouse facilities that can be identified in the product, such as the salary of the person who works at the warehouse facilities, distribution centres, etc.), and 3) Direct Expenses (Direct expenses are those expenses that are levied during the production of goods or provision of services, e.g. expenses of a 3PL company that determine its gross profit, expenses such as salary, telephone bill, transportation and rent). Direct costing has a number of advantages, such as: at first, income is not affected by changes in production volume, also, fixed costs are more visible, and managers have a clear picture about direct costing reports because data are organized by behavior and because direct costing is much closer to cash flow. 
Absorption Costing treats all manufacturing costs as product costs, regardless of whether they are variable or fixed (Garrison, Noreen and Brewer, 2004). That simply means that all of the manufacturing costs are absorbed by the units produced. The cost of a finished unit in inventory will include direct materials, direct labor, and both variable and fixed manufacturing overhead. Accounting managers find in Absorption Costing a number of advantages, such as: fixed costs are recovered; the total cost is identified, and what's more, it is a useful method of pricing and identifies the profitability of different products and services.

Over the last decades a new costing approach has emerged; the Activity-Based Costing (ABC). $\mathrm{ABC}$ is a method for developing cost estimations in which the project is subdivided into discrete, quantifiable activities or a work unit (Cooper and Kaplan, 1988; Innes, Mitchell, and Sinclair, 2000). Thus, the activity must be definable clearly where productivity can be measured in units (e.g., number of orders processes versus man-hours). The next step is the cost estimation for each activity regarding all labor, materials, equipment, and subcontracting costs, including overhead, for each activity. Finally, each complete individual estimate is added to the others to obtain an overall estimate. $\mathrm{ABC}$ is a powerful tool, but it is not appropriate for all cost estimates as $\mathrm{ABC}$ methodology is used when a project can be divided into defined activities. This is true in case of the Third Party Logistics, in which a number of systematic and standardized logistics processes take place.

Finally, in order to compare the above costing systems, Table 1 illustrates the main differences between direct and absorption costing systems (Garrison, Noreen and Brewer, 2004).

Table 1. Comparison of direct and absorption costing systems

\begin{tabular}{|c|l|c|}
\hline $\begin{array}{c}\text { Absorption } \\
\text { Costing }\end{array}$ & $\begin{array}{c}\text { Activity-based } \\
\text { costing }\end{array}$ \\
\hline Product cost & $\begin{array}{l}\text { Direct materials } \\
\text { Direct Labor } \\
\text { Variable Manufacturing overhead }\end{array}$ & Product cost \\
\hline Period cost & $\begin{array}{l}\text { Variable selling and administrative } \\
\text { expenses } \\
\text { Fixed selling and administrative } \\
\text { expenses }\end{array}$ & Period cost \\
\hline
\end{tabular}

Table 2. Comparison of Activity-Based Costing and Traditional Costing Methods

\begin{tabular}{|l|l|}
\hline \multicolumn{1}{|c|}{ Traditional costing } & \multicolumn{1}{|c|}{ Activity-based costing } \\
\hline $\begin{array}{l}\text { Only manufacturing costs are } \\
\text { assigned to products }\end{array}$ & $\begin{array}{l}\text { Manufacturing as well as non- } \\
\text { manufacturingcosts can be assigned } \\
\text { to products (somemanufacturing } \\
\text { costs may be excluded fromproduct } \\
\text { costs) }\end{array}$ \\
\hline $\begin{array}{l}\text { Selling, general and administrative } \\
\text { expenses are period expenses }\end{array}$ & $\begin{array}{l}\text { Selling, general and administrative } \\
\text { expensescan be assigned to } \\
\text { products if there is a cost effect } \\
\text { relation between them }\end{array}$ \\
\hline $\begin{array}{l}\text { A single overhead rate is used for the } \\
\text { entire factory: direct labour- or } \\
\text { machine-hours }\end{array}$ & $\begin{array}{l}\text { A number of overhead cost pools } \\
\text { exist, with different allocation bases }\end{array}$ \\
\hline $\begin{array}{l}\text { Costs of unused capacity are } \\
\text { assigned to products too }\end{array}$ & $\begin{array}{l}\text { Costs of idle capacity are not } \\
\text { assigned to products (only the costs } \\
\text { of capacity they use) }\end{array}$ \\
\hline
\end{tabular}

Furthermore, the main differences between the Activity-Based Costing with Traditional Costing Methods are presented in the Table 2 (Karadað, Samli and Öztürk, 2009):

\section{An empirical survey for costing systems by Greek 3pl's companies}

A survey consisting of a cover letter and a questionnaire were mailed from September 2008 to December of the same year, to the managers of the 50 largest Third Party Logistics Providers in Northern Greece as identified by the Plant Management magazine (www.plant-management.gr). Of the 50 questionnaires distributed, 33 completed questionnaires were returned by those surveyed. The effective response rate was very high (66\%). A corresponding number of interviews were arranged with the above managers. A regression analysis and Kruskal-Wallis tests have been applied for the statistical analysis.

The main objectives of the survey were:

1. The identification of the costing system that the examined 3PL's companies have adopted and used.

2. The identification of the Accounting Manager.

3. The estimation of the indirect costs

4. The estimation of the degree of satisfaction by managers regarding the costing system. 
5. The identification of the problems regarding the existed costing system.

6. The examination of the costing system and information availability.

The results of the analysis are presented and discussed in this section. The first question / objective referred to the costing system that companies maintain and use. Sixteen $(48.5 \%)$ of the 33 respondents use Direct Costing, 9 of them (27.3\%) use Absorption Costing, 7 (21.2\%) used Activity Based Costing, and one company use other costing system (3\%) (Table 3).

Table 3. Costing System

\begin{tabular}{|l|c|c|}
\hline \multicolumn{1}{|c|}{ Sector } & Number & Percentage \\
\hline Direct costing & 16 & 48.5 \\
Absorption costing & 9 & 27.3 \\
Activity Based Costing & 7 & 21.2 \\
Other & 1 & 3 \\
\hline Total & 40 & 100.00 \\
\hline
\end{tabular}

\section{Accounting Manager}

Half of the companies (48,5\%) have established in their organizational structure the position of Accounting Manager. Specifically, all of the companies that use $\mathrm{ABC}$ have an Accounting Manager (this is expected since it is one of the critical success factors of the ABC system).

\section{Indirect costs}

As apportionment bases of the indirect cost the following approaches are used:

- Direct labor cost $(75,8 \%)$.

- Direct labor working hours $(54,5 \%)$, and

- Direct materials cost (51,5\%).

Working units (such as equipments, systems for in-bound logistics, etc.) are used in a lower degree $(33,3 \%)$, while the working hours of the equipment are not used.

\section{Satisfaction level}

Regarding the degree of satisfaction, which was the second objective of the survey, $63.3 \%$ of the companies indicate that they are neither satisfied nor dissatisfied with the costing system they use (Figure 1). A percentage of $36.4 \%$, point out that they are satisfied with their costing system. According to the findings, the 3PL's which used ABC are more satisfied that the others. During the interviews, most of the managers identify the following advantages of the $A B C$ approach:

1) $A B C$ supports the appreciation of the way in which customers directly affect the cost structure of the business in order to analyze customer profitability in a more efficient way,

2) $A B C$ focuses on the activities that add value, from the customer's point of view, which is a critical success factor of 3PL providers, and

3) $\mathrm{ABC}$ helps performing capacity analysis in order to allocate the right resources to the customer, which is also crucial in logistics management.

Figure 1. Degree of satisfaction

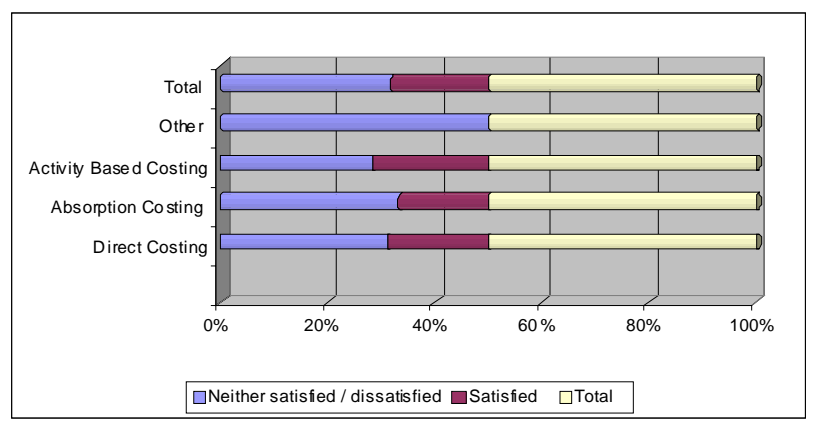

Problems with the costing system

Finally, in order to assess the problems that Third Party Logistics companies confront with their costing system, a hierarchical multiple regression was applied. In general, the hierarchical multiple regression is used to evaluate the relationship between a set of independent variables and the dependent variable, controlling for or taking into account the impact of a different set of independent variables on the dependent variable.

In this survey, the following independent variables were selected and used:

- The software package that companies use (according to the findings, all of the companies use Accounting Software packages, $81.8 \%$ use also Payroll modules / applications, and MIS a percentage of $39.4 \%$ ). 
- Variables that refer to the operation of the company (such as, if the company has established a job position for Accounting Management, if the company uses in the accounting plan fourth-level codes, etc.), and finally

- The costing system.

The following problems were examined:

- Wrong allocation of indirect costs,

- Inability for the calculation of logistics services' efficiency,

- Difficulties in raw data gathering process,

- Delays in the acquisition of right costing information.

The most significant problem according to the answers of the managers, was the incorrect allocation of indirect costs to the provided services (Average $=2.36$ ) (Likert scale, from 1 / Non-significant problem to $5 /$ Very significant problem). The problem of the acquisition of right costing information follows (Average $=2.30$ ). Inabilities for the calculation of logistics services' efficiency, as well as, the difficulties in raw data gathering process were less significant problems (1.91 and 1.85).

Further statistical tests revealed the following:

- For the problem of incorrect allocation of indirect costs to the provided services: the accounting software package is responsible for a significant percent of the variance of the dependent variable, while they explain the $31.4 \%$ of the total variance $(\mathrm{F}=8.822, \mathrm{p}=0.000)$. Moreover, the variables, which refer to the operation of the company explain the $23.7 \%$ of the total variance $(\mathrm{F}=21.554, \mathrm{p}=0.000)$. The deployed costing system has a significant effect on the problem of the wrong allocation of indirect costs to the provided services since it explains the $39.1 \%$ of the total variance $(\mathrm{F}=4,494, \mathrm{p}=0,006)$.

- Regarding the inability for the calculation of logistics services' efficiency: the accounting software package explains the $39 \%$ of the total variance $(\mathrm{F}=100.392, \mathrm{p}=0.000)$, while the variables which refer to the operation of the company explain the $11.3 \%$ of the total variance. Once gain, the costing system, has significant effect on the problem of the inability for the calculation of logistics services' efficiency $47.4 \%$ ( $\mathrm{F}=9.654$, $\mathrm{p}=0.000$ ).

- About the difficulties in raw data gathering process: the accounting software package has effect on the problem and explains the $17.9 \%$ $(\mathrm{F}=7.035, \mathrm{p}=0.001)$, while the variables those refer to the operation of the company explain the $11.9 \%$ of the total variance $(\mathrm{F}=161.638$, $\mathrm{p}=0.000$ ). The costing system, explains $62.4 \%$ of the total variance $(F=11,610, p=0,000)$, regarding the difficulties in raw data gathering process.

- Finally, regarding the problem of the acquisition of right costing information: the applied software package explains $25.6 \%$ of the total variance $(F=10.163, p=0.000)$. On the contrary, the variables that refer to the operation of the examined companies have no significant effect on the problem (5\%), while the costing system is responsible for a significant percent of the variance of the dependent variable, in the specific problem $53.4 \%(\mathrm{~F}=8,025, \mathrm{p}=0,000)$.

\section{Costing system and information availability}

Regarding the information that is provided by the costing systems the results reveal that most companies have information about the cost of their products and services $(87,9 \%)$, the re-engineering of specific activities and/or processes $(66,7 \%)$ and the cost per production department of the company $(63,6 \%)$.

On the contrary, the information about the cost of activities is low $(33,3 \%)$, as well as, the cost every cost centre of the company $(27,3 \%)$, and the costs of the parameters that are responsible for the creation of cost $(21,2 \%)$.

Kruskal-Wallis test showed that the costing system presents statistically strong relationships with the information provision for:

- The re-engineering of specific activities and/ or processes $(\div 2=11,896, \mathrm{df}=3, \mathrm{p}=0,008)$, and

- The costs of the parameters that are responsible for the creation of cost $\left(\div^{2}=20,393\right.$, $\mathrm{df}=3, \mathrm{p}=0,000$ ).

In both situations the statistical relationship is focused on the 3PL's who use direct costing and absorption costing. Specifically, the Mann-Whitney tests confirm that the companies that use $\mathrm{ABC}$ have 
better comprehension regarding the re-engineering of processes and activities (mean Rank Direct Costing $=15,81$ and mean Rank Standard Costing $=8,00$ ) with Yes and No as the answers', as well as, for the factors / parameters that create cost compared with those that use absorption costing (mean Rank Standard Costing $=11,50$ and mean Rank Activity Based Costing=6,17).

The information provision is used mainly for the abolition of non-added value processes $(72,7 \%)$, the establishment of new commercial policy $(69,7 \%)$ and the performance measurement $(54,5 \%)$. The abandonment of non-effective products and the reengineering of the customers' portfolio and the costing policy are affected in a minor way $(45,5 \%$ and $21,2 \%$ respectively).

The Kruskal-Wallis tests show that the costing system affects the usage of information at: the reengineering of the customers' portfolio and the commercial policy $(\div 2=16,463, \mathrm{df}=3, \mathrm{p}=0,001)$ and the abandonment of non-effective products and services $(\div 2=19,269, \mathrm{df}=3, \mathrm{p}=0,000)$.

Overall, Mann-Whitney tests revealed that the companies that use $\mathrm{ABC}$ systems are more possible to use the information for the desertion of nonefficient products and for the re-engineering of their customers portfolio and commercial policies compared with the companies that use absorption costing system. Furthermore, the companies that use $\mathrm{ABC}$ systems are more likely to use the information for the re-engineering of their customers' portfolio and commercial policies compared with the companies that use direct costing system(mean Rank Direct Costing $=15,06$ against mean Rank Activity Based Costing=5,00).

\section{Conclusions}

In today's dynamic and demanding business environments, logistics processes are very complex especially from the viewpoint of provided services' costs. On the other hand, logistics has the greatest potential for costs savings and higher quality through integrated management.

The main objective of this paper was the identification and evaluation of the costing system that Third Party Logistics companies in Northern Greece have used. The most significant findings of the survey were the following:
- Most companies use and exploit the Direct and Absorption costing.

- Companies that used Activity-Based Costing are more satisfied that the companies that maintain other costing systems.

- The most significant problems that the companies indicated regarding the costing procedure were the incorrect allocation of indirect costs to the provided services and the problem of the acquisition of right costing information.

- The costing system that companies use is responsible for the above problems.

Future research involves the exploration of the Third Party Logistics costing approaches after the emergence of the Enterprise Resource Planning (ERP) systems and / or the Logistics Information Systems (LIS). Moreover, the assessment of the exact procedures of the Activity Based Costing that logistics outsourcers use.

\section{References}

Blanchard, D., (2007), Supply Chain Management - Best Practices, Wiley \& Sons Inc, New Jersey.

Christopher M., (2005), Logistics and Supply Chain Management, Prentice Hall, Great Britain.

Cooper R., and Kaplan R., (1987), How cost accounting systematically distorts product costs, In Accounting Management - Field Study Perspectives, Bruns Jr. W., Kaplan, R.S. (Eds.), Harvard Business School Press, Boston, pp. 204-228.

Cooper R., and Kaplan R., (1988), Measure costs right: make the right decisions, Harvard Business Review 66 (5), pp. 96-103.

Ellram L., and Cooper M., (1996), Supply Chain Management, Partnerships, and the shipper-Third Party Relationship, The International Journal of Logistics Management 1 (2), pp. 22-4.

Garrison R., Noreen E., and Brewer P. (2004), Managerial Accounting, McGraw-Hill, $11^{\text {th }}$ edition.

Goldsby T., and Closs D., (2000), Using activity-based costing to reengineer the reverse logistics channel", International Journal of Physical Distribution \& Logistics Management 30 (6), pp. 500-514.

Innes J., Mitchell F., and Sinclair, D., (2000), Activity-based costing in the UK's largest companies: a comparison of 1994 and 1999 survey results, Management Accounting Research 11, pp.349-62. 
Kaplan R., (1984), Annual review of applied linguistics, Rowley, MA: Newbury House.

Karadað I., Samli P. and Öztürk N., (2009), Using linear programming to compare direct and absorption costing, Main report submitted to The Department of Industrial Engineering of Çankaya University in partial fulfillment of the requirement for IE 456 Mathematical Modeling and Applications course, Available at: http://academic.cankaya.edu.tr/ benhur/ie456/Projects/Project\%20Reports/Group-6Report.pdf (2009).
La Londe B., and Pohlen T., "Issues in Supply Chain Costing", International Journal of Logistics Management 7 (1), pp. 1-12, (1996).

McIvor R., (2000), A practical framework for understanding the outsourcing process, Supply Chain Management: An International Journal 5 (1), pp. 22-36.

Pohlen T., and La Londe B., (1994), Implementing activitybased costing $(\mathrm{ABC})$ in logistics, Journal of Business Logistics 15 (2), pp.1-23.

Titone R., (1996), Moving beyond JIT to logistics planning", IIE Solutions 28 (2), pp. 1-10.

Dr. Anastasios Hatzis holds a PhD from the Department of Applied Informatics, University of Macedonia, Greece. He is now an Assistant Professor at the Department of Accounting at the Alexander Technological Educational Institute of Thessaloniki (ATEI), Greece. His research interests include: Accounting and Costing systems.

Mrs. Agathi Koulidou holds a Bachelor from the ATEI. She is a postgraduate student now studying Accounting and Finance at the Department of Accounting and Finance at University of Macedonia. She is an Adjunct Lecturer at the Department of Accounting at the ATEI Thessaloniki. Her research interests include: Accounting Information Systems, Costing and Accounting.

Dr. Dimitris Folinas is an Assistant Professor at the Department of Logistics in the ATEI of Thessaloniki, Greece. He possesses a Ph.D in e-Logistics from the University of Macedonia, Thessaloniki, Greece and a Master of Information Systems from the same Institution. He is the author and co-author of over 90 research publications, and as a researcher he has prepared, submitted and managed a number of projects funded by National and European Union research entities. His research interests include: Logistics and Supply Chain Management, e-Logistics, Supply Chain Integration, Logistics Information Systems and Enterprise Information Systems. 